NOTICE: this is the author's version of a work that was accepted for publication in Journal of International Financial Markets, Institutions and Money. Changes resulting from the publishing process, such as peer review, editing, corrections, structural formatting, and other quality control mechanisms may not be reflected in this document. Changes may have been made to this work since it was submitted for publication. A definitive version was subsequently published in Journal of International Financial Markets, Institutions and Money, Vol. 34 (2015). DOI: 10.1016/j.intfin.2014.11.001 


\section{Asymmetric volatility response to news sentiment in gold futures}

This paper seeks to consider the relationship between the sentiment of newswire messages and the volatility of returns in the gold futures market. In particular, answers are sought to two key questions: Firstly, how is the volatility of returns in the gold futures market influenced by the sentiment of non-scheduled news events? Secondly, is this news-volatility relationship affected by the state of the business cycle? The empirical evidence points to the sentiment of newswire messages having a significant asymmetrical impact on volatility such that negative news has a significantly greater impact on volatility than does positive news. There is evidence to suggest that participants in the gold futures market initially over-react to newswire messages and this is subsequently reversed. The recessionary environment of Q4 2007 - Q2 2009, serves to greatly increase the volatility response to newswire messages.

Keywords: Gold, Trading Behaviour, News Sentiment, Volatility, Asymmetric Response JEL Codes: C2, G0, G10, G13, G14 
Gold is a way of going long on fear, and it has been a pretty good way of going long on fear from time to time. But you really have to hope people become more afraid in a year or two years than they are now.

Warren Buffett (2012)

\section{Introduction}

Historically, investors have utilized gold as a store of value and a means of exchange, and for much of the 20th century the gold-standard exchange rate placed it at the very centre of the global financial system. Today's media ${ }^{1}$ often cites the safe haven status of gold during periods of financial market turmoil as the key rationale for purchasing gold. Baur and Lucey (2010) find that gold is a hedge against stocks on average and a safe haven in extreme market conditions, although this property is such lived. Baur and McDermott (2010) provide further evidence in support of gold's safe haven status for developed market during the recent global financial crisis (GFC). Increased stock market volatility in the period following the crisis has induced demand for gold as an investment from both retail and institutional investors; this has been further enabled by an increase in the range of products such as exchange traded funds and demand for gold for investment purposes now constitutes approximately $35 \%$ of total annual demand for the precious metal ${ }^{2}$.

The value of gold has divided opinion amongst academics and the investing community. Whilst some experts ${ }^{3}$ note that gold is essentially overvalued, primarily since it does not provide any income, others (McCown and Zimmerman, 2006; Draper et al., 2006) highlight the empirical support for the diversification benefits of gold and Capie et al. (2005) notes that gold protects against exchange-rate risk for investors with U.S. dollar holdings. Erb and Harvey (2013) add to the debate by considering many of the arguments for holding gold within a portfolio; they report that gold is only a good inflation hedge for holding-periods much longer than relevant for most investors, it is an unreliable currency hedge, and "should not be counted as a safe haven in times of extreme stress". However, there is support for the current historically high gold price should demand trends from emerging markets follow those in developed markets, owing to the relatively

\footnotetext{
${ }^{1}$ For example: http://www.forbes.com/sites/kitconews/2013/08/27/focus-gold-rises-on-safe-haven-buysover-syria-technical-charts-fed-qe-debate/ and http://www.reuters.com/article/2012/11/16/marketsprecious-idUSL5E8MGBEA20121116

${ }^{2}$ Source: World Gold Council - Gold Demand Trends

${ }^{3}$ For instance, Warren Buffett in his Feb 2012 annual shareholder letter notes that "gold has two significant shortcomings, being neither much use nor procreative". http://www.berkshirehathaway.com/letters/2011ltr.pdf
} 
fixed supply of gold. Frequent media reports on the large holdings of gold assets by a range of investors, most notably hedge funds, and the spectacular gains and losses witnessed in those funds ${ }^{4}$, suggest that it is of some importance to understand how such markets respond to news events.

Much of the extant literature in the field of the news impact on asset prices has focused on specific and easily identifiable news events, such as macroeconomic announcements and earnings results, where the event is scheduled in advance and the news effect is readily quantifiable. Fleming and Remolona (1997) argue that sharp price movements, and the accompanying increase in volatility, are attributable to changes in expectations shared by investors. Ederington and Lee (1993) suggest that volatility may remain high for some period after a scheduled macroeconomic announcement since full information only arrives gradually; Frino and Hill (2001) and Smales (2013) also find an increase in volatility in the period prior to data releases. Lee (1992), Lee, Mucklow and Ready (1993), and Krinsky and Lee (1996) observe higher trading activity and higher volatility following earnings announcements. Kim and Verrecchia (1994) and Gerlach (2005) propose that such results stem from imperfect, and asymmetric, information.

More recently, the literature has utilized more comprehensive datasets to examine the relationship of non-scheduled news on asset returns, and the volatility of such returns. Brooks et al. (2003) find that only new and unpredictable information moves prices, while Antweiler and Frank (2004) find that messages posted on Internet news boards help to predict market volatility. Kalev et al. (2004) note a positive and significant impact of the arrival rate of selected nonscheduled news variables on the conditional variance of stock returns, even after controlling for the potential effects of trading volume. Such results are consistent with the mixture of distributions hypothesis (MDH) which forms the basis of an explanation for the relationship between the rate of information arrival and measures of market activity, such as asset volatility and trading volume; an important implication been that observed patterns of asset volatility are reflective of similar patterns in information flow.

Tetlock (2007) initiated the first concerted effort to quantify the tone and sentiment of news-message text - information that is essentially qualitative in nature - in order to examine the

\footnotetext{
${ }^{4}$ For example: http://www.bloomberg.com/news/2013-07-08/paulson-s-pfr-gold-fund-fell-23-in-june-65this-year.html
} 
relationship between news and asset prices. Tetlock (2007) assigns a sentiment score to Wall Street Journal articles using the General Inquirer database and, consistent with theoretical models of noise and liquidity traders, finds that negative stories predict low market returns. In a similar framework, Tetlock et al. (2008) argue that the linguistic content of news messages captures hardto-quantify aspects of fundamentals that are quickly impounded into asset prices.

Modern technology has enabled the development of news analytics software packages, such as Thomson Reuters News Analytics ${ }^{5}$ (TRNA), which utilize advanced algorithms to assign sentiment indicators to non-scheduled news releases in real-time and allow a more comprehensive quantitative examination of the effect of news on asset prices. Using news sentiment measures derived from such software, Groß-Klußmann and Hautsch (2011) note that high-frequency movements in returns and return volatility can be explained by the mostly nonscheduled news arrivals during a day. Leinweber and Sisk (2011), Smales (2012), and Riordan et al. (2013) find that negative news is more informative and the reaction to negative news is more vigorous and thus negative sentiment signals are more exploitable. Most recently, the results of Ho, Shi and Zhang (2013) confirm the significant impact of firm-specific news sentiment on intraday volatility persistence, even after controlling for the potential effects of macro news and again report the greater impact on return volatility of negative news. Until recently the data provided by news sentiment software vendors has focused on firm-specific news and so the impact of non-scheduled news on asset returns, and volatility, has largely been ignored outside of the stock market context.

A section of the existing literature has focused on how the news effect on financial market returns and volatility varies over time. Kandel and Stambaugh (1990), McQueen and Roley (1993) and Veronesi (1999) suggest that the difference in the response to news is dependent on the business cycle, while Roley and Sellon (1995) find that the relationship between news and longterm interest rates is likely to vary over the business cycle as market participants alter their views on the persistence of policy actions. Jensen et al. (1996) also note that business-conditions have an influence on expected asset returns as a result of the associated monetary environment.. Hamilton and Lin (1998) note that recession is the primary factor that drives fluctuations in the volatility of stock returns. Dzielinski (2011) identifies a news premium and suggests that this primarily relates to the high impact of news in situations of general uncertainty that accompany

\footnotetext{
${ }^{5}$ Formerly titled Thomson Reuters NewsScope Sentiment Engine (RNSE)
} 
recession and financial crisis. Garcia (2013) examines the effect of news sentiment on stock prices throughout the $20^{\text {th }}$ century and reports that the predictability of stock returns using news content is concentrated in recessions. In a similar vein to Dzielinski (2011), Garcia (2013) suggests that the findings are a consequence of recession inducing heightened investor attention and a greater sensitivity to news owing to the emotional impact on decision-making. Since gold is often viewed as a safe haven in times of economic crisis, and hence investors are likely to hold a greater portfolio weighting of gold during such periods, it is pertinent to consider how the state of the business cycle will impact the volatility response to non-scheduled news events.

This article seeks to answer two key questions. Firstly, how is the volatility of returns in the gold futures market influenced by the sentiment of non-scheduled news events? In particular, is the asymmetric response to negative news found in stock and bond returns also evident in gold market returns? Secondly, is this news-volatility relationship affected by the state of the business cycle? This article contributes to the literature, and investor understanding of the gold market, in three important ways. Firstly, this is the first study of the influence of news sentiment on market returns that does not utilise firm-specific data. Secondly, the extant work on the impact of news events in equity markets is extended to a rapidly expanding asset class that is appearing in the diversified portfolios of many investors; it is salient for such investors to have an understanding of how news events will impact return volatility when holding the asset within their portfolio. Thirdly, since one of the primary reasons that many investors add gold to their portfolios is the perceived safe haven quality it is important to understand how the relationship with news evolves with respect to underlying macroeconomic conditions, particularly during times of economic turmoil such as those occurring in recession.

The key findings may be summarized as follows. First, there is significant evidence that newswire messages, and the sentiment of those messages has a significant impact on the volatility of returns in the gold market. Second, both conditional, and unconditional, analysis of the newsvolatility relationship indicates that there is an asymmetric response of volatility to news such that negative news has a significantly greater impact on volatility than does positive news. Third, there is some support for the notion that participants in the gold futures market initially overreact to newswire messages and this is reversed in subsequent periods. Lastly, the state of the business cycle, particularly the recessionary environment of Q4 2007 - Q2 2009, serves to greatly increase the magnitude of the response to newswire messages. The results will be important to 
investors attracted to gold investments as a safe-haven during recessionary environments since they must accept a higher volatility response to news in return for the additional conditional returns gained during such periods.

The remainder of this paper is organized as follows: Section 2 discusses the nature of the data used in this paper, with a particular focus on the measure of news sentiment measure. Section 3 describes the econometric models utilised in the empirical analysis. Section 4 presents empirical evidence on the relationship between news sentiment and return volatility in the gold futures market, and the influence of the business cycle on this relationship. Section 5 provides a robustness test. Section 6 concludes the paper.

\section{Data}

\section{$2.1 \quad$ Data on News Sentiment Indicators}

News sentiment data for the period $2^{\text {nd }}$ January $2003-31^{\text {st }}$ October 2012 is obtained from Thomson Reuters News Analytics (TRNA; an algorithmic text-reading tool provided by SIRCA6). Previously, news analytics software has focused on firm-specific news with the result that the literature has focused on equity markets and ignored the impact of non-scheduled newswire events in other important markets. However, TRNA now provides additional data to enable the study of news sentiment outside of the equity market context. The TRNA data set describes each news item with more than 40 pieces of metadata, with the most important in the context of this investigation been:

- Identifier of the commodity mentioned in the news;

- Timestamp, indicating the arrival of the news article to the nearest second;

- Sentiment, a discrete variable indicating whether the news was positive $(+1)$, neutral $(0)$ or negative (-1). This measure is based on a purely linguistic analysis of text and does not contain any form of market feedback.

- Sentiment probabilities, a set of variables which shows the probability of assigning each of the possible sentiment indicators to the news item, with the indicator assigned to the variable with the highest probability. Intuitively, a news item with a positive news probability of 0.8 can be seen as more positive than one with a probability of 0.2 .

\footnotetext{
${ }^{6}$ Securities Industry Research Centre of Asia-Pacific
} 
- Relevance, a continuous variable on the $[0,1]$ interval indicating how prominently the commodity was mentioned in the news article. A relevance score of 1 generally indicates that the commodity was mentioned directly in the headline.

- Novelty, which shows whether the news item is linked to other similar news items or is an item in a sequence of updated news items. In order to ensure that analysis focuses on the arrival of new information, items with a Linked Count greater than 0 or a Sequence Number greater than 1 are excluded from the sample.

An example of a positive news event would be the message broadcast at $14: 02: 44$ on $4^{\text {th }}$ June 2008 - "Gold to hit record above \$1,000 per oz this year". A negative sentiment score was attached to the broadcast text "Asian shares fall as Eurozone yields rise" on $15^{\text {th }}$ November 2011 at 11:00:48. Groß-Klußmann and Hautsch (2011) and Smales (2012) observe that only news categorized as highly relevant has a significant impact on market prices, hence news that is not classified as highly relevant is removed from the sample ${ }^{7}$. The sentiment of news items which arrive during each trading day are aggregated into a daily sentiment measure. Following Dzielinski (2011), the sentiment of each news item is multiplied with its probability to compute a weighted average of the prevailing sentiment for that day (Eq.1).

$$
\text { News }_{t}=\frac{\sum 1 \cdot \text { prob }_{\text {positive }}+\sum(-1) \cdot \text { prob }_{\text {negative }}}{n_{\text {positive }}+n_{\text {neutral }}+n_{\text {negative }}} \in[-1,1]
$$

Although neutral news items do not enter the sentiment calculation in the numerator (owing to their sentiment of 0 ) the number shows up in the denominator pushing the measure downward, so that a day with many neutral news items would still be classified as neutral. This procedure is repeated for each trading day to obtain a complete history of news days and their respective sentiment classification.

\subsection{Data for Gold Futures Market}

The empirical analysis in this paper considers the gold futures market ${ }^{8}$ (GC). The most actively traded gold futures are those traded on COMEX (owned by Chicago Mercantile Exchange since August 2008), where the contract size is 100 troy ounces and the minimum price fluctuation is $\$ 0.10$ per troy ounce. For the period $2^{\text {nd }}$ January $2003-31^{\text {st }}$ October 2012, a continuous series of returns is created for using the settlement prices obtained from Thomson Reuters Tick History

\footnotetext{
${ }^{7}$ The original sample of 98,096 news releases is reduced to 63,486 items.

${ }^{8}$ Reuters symbol $G C$.
} 
(TRTH) provided by SIRCA. The return is measured as the log of the difference in daily settlement prices $\left(\ln \left(f_{t} / f_{t-1}\right)\right)$; with the nearest-to-maturity contract used and switching to the second-nearest contract when the liquidity (measured by open interest) becomes greater. Two measures of volatility are also captured; the first (Vol_1) represents the daily standard deviation of 5-minute returns, and the second (Vol_2) embodies the average daily standard deviation of changes in quote midpoints. Figure 1 depicts the evolution of the price of gold futures over the 10-year sample period, along with the S\&P500 Index for comparative purposes. During this period, gold futures have exhibited a significant up-trend with prices rising from $\$ 346.50$ in January to 2003, to $\$ 1,719.10$ as of October 2012 (a high of $\$ 1,874.40$ was posted on 02-Sep-2011). $<$ Insert Figure 1>

\subsection{Business Cycle}

In order to investigate the influence of the business cycle on the reaction of gold futures to news articles a dummy variable $\left(\operatorname{Rec}_{t}\right)$ is introduced to signify whether or not the economy is in recession; this variable is equal to 1 if the given trading day occurs during the recession and 0 otherwise. Additionally, an interaction term $\left(\mathrm{News} \cdot \mathrm{Rec}_{t}\right)$ is introduced to indicate whether news sentiment occurred during a recessionary period on day $t$. The dates of recession are defined by the National Bureau of Economic Research (NBER) as "demonstrating a significant decline in economic activity spread across the economy, lasting more than a few months, normally visible in real GDP, real income, employment, industrial production, and wholesale-retail sales”. The NBER defined recession in this sample period is that of Q4 2007 - Q2 2009, a period that coincides with the global financial crisis.

\section{$<$ Insert Table 1>}

Table 1 presents descriptive statistics for the data utilised in this study. Panel A demonstrates that daily returns from gold futures were generally positive during the sample period $^{9}$, with no evidence of return predictability. Consistent with positive returns during the sample period, the sentiment of news messages is also positive on average; although it should be noted that the standard deviation is large relative to the mean and there is significant positive partial autocorrelation of one lag. In-line with rapidly declining equity markets, and (still) expansionary monetary policy following the onset of the GFC, changes in the dividend yield are largely positive while interest rates are generally falling. The two measures of volatility display significant evidence of autocorrelation.

\footnotetext{
${ }^{9}$ This should be no surprise given the significant uptrend in gold prices evidenced in Figure 1.
} 
Panel B disaggregates the sample period into that occurring prior to the Global Financial Crisis (GFC) related recession of October 2007 - June 2009, the crisis period, and the post-crisis period. Gold futures returns are positive in all sub-periods, with the highest return occurring post-crisis $^{10}$ and the greatest standard deviation of returns arising during the crisis period. Newswire stories are also more frequent during the crisis period. News sentiment tended to be positive during the bull market prior to the crisis, and extremely negative during the crisis. In the aftermath of the GFC, news sentiment has remained negative on average and this is likely to be at least partly due to the ensuing European sovereign debt crisis. Both volatility measures increase markedly during recession (as does the variability of those measures) and remain high in the following period. The descriptive statistics are consistent with the mixture of distributions hypothesis

\section{Econometric model}

This section provides the econometric approach taken to develop an understanding of the relationship between news sentiment and volatility in the gold futures market. The baseline model utilises a regression specification of the form:

$$
\Delta \operatorname{Vol}_{i, t}=\alpha_{c}+\sum_{j=0}^{n} \alpha_{j} N e w s_{t-j}+\alpha_{1} \operatorname{Rec}_{t}+\sum_{j=0}^{n} \alpha_{k+j} N e w s \cdot \operatorname{Rec}_{t-j}+\alpha_{2} \operatorname{Day}_{t}+\varepsilon_{t}
$$

Where the dependent variable is the first difference in the volatility measure during period $t, N e w s_{t-j}$ is the news sentiment measure of lag $j, \operatorname{Rec} t$ is a dummy variable indicating whether the U.S. economy is in recession or not, and the interaction variable of $N_{e w s} \cdot R_{e c t}-j$ indicates that the unscheduled news release on lag $j$ occurred during a recessionary period, Dayt is a day of the week dummy variable included to account for the well-documented day of the week effect on market activity ${ }^{11}$, and $\varepsilon_{t}$ is the error term. Empirical analysis also considers an augmented version of this model whereby the news sentiment measures are disaggregated into positive and negative news sentiment to capture any asymmetric effect. The positive (negative) news sentiment variable is equal to Newst if the news sentiment is greater (less) than zero and zero otherwise; thus the positive (negative) news variable is $\geq(\leq) 0$. A news frequency variable is

\footnotetext{
${ }^{10}$ One rationale for this may be the perceived safe haven nature of gold during the European debt crisis.

${ }^{11}$ For example: Foster and Viswanathan (1990, 1993), French and Roll (1996), and Han et al. (1999)
} 
added to allow for the impact of information arrival on asset volatility as suggested by the mixture of distributions hypothesis.

Conditional returns and volatility are modelled using the Threshold Generalized Auto Regressive Conditional Heteroskedastic (TGARCH) model of Glosten et al. (1993) and Zakoian (1994); this model explicitly allows for the examination of asymmetric return innovations (news) on gold market volatility. Eq.(3A) and Eq.(3B) outline the TGARCH specification used to model the conditional effect of news sentiment and the stage of the business cycle:

$$
\begin{gathered}
y_{t}=\beta_{c}+\beta_{1} y_{t-1}+\sum_{i=0}^{k} \beta_{i} N e w s_{t-i}+\beta_{2} \operatorname{Rec}_{t}+\beta_{3} \text { Day }_{t}+\varepsilon_{t} \\
\sigma_{t}^{2}=\lambda_{c}+\lambda_{1} \varepsilon_{t-1}^{2}+\lambda_{2} \sigma_{t-1}^{2}+\lambda_{T} \varepsilon_{t-1}^{2} \Gamma_{t-1}+\sum_{i=0}^{k} \lambda_{i} N e w s_{t-i}+\lambda_{4} R_{t}+\lambda_{5} \text { Day }_{t}
\end{gathered}
$$

The conditional mean equation (3A) for the returns in the gold futures market series $\left(y_{t}\right)$ is expressed as a function of past returns $\left(y_{t-1}\right)$, news sentiment $\left(N e w t_{t-i}\right)^{12}$, a dummy variable indicating whether the economy is in recession $\left(R_{t}\right)$, and a dummy variable for the day of the week effect $($ Dayt $)$. Similarly, the conditional variance equation for the returns in the time series is expressed as a function of the past variance of returns, contemporaneous and lagged news sentiment a vector of macroeconomic variables and a dummy variable for the day of the week effect. Asymmetry of innovation is incorporated into the TGARCH model by the variable $\Gamma_{t .} \Gamma_{t}=$ 1 if $\varepsilon_{t}<0$ and 0 otherwise; this allows for good news $\varepsilon_{t-1}>0$ and bad news $\varepsilon_{t-1}<0$ to have differential effects on the conditional variance and thus $\lambda_{t} \neq 0$ will imply an asymmetric news impact.

\section{Empirical analysis}

\subsection{Unconditional analysis of news sentiment and measures of volatility}

In this section the unconditional relationship between the volatility of gold futures and measures of news sentiment is investigated. The results for regression specifications of the form noted in Eq. (2) are presented in Table 2 for both measures of daily volatility.

$<$ Insert Table 2>

\footnotetext{
${ }^{12}$ Contemporaneous news sentiment together with significant lags are included in the regression equation, in reality this means only contemporaneous news and news lagged by one-period are included.
} 
Panel A of Table 2 presents the results for the baseline model, i.e. without the disaggregation of news into positive and negative components. The intercept is generally negative, across all specifications, indicating that volatility tends to decrease in the absence of news events. There is a negative and highly significant contemporaneous relationship between news sentiment and volatility such that an increase (decrease) in news sentiment results in lower (higher) volatility in the gold futures market. The positive (although not well-defined) coefficient for lagged news sentiment is suggestive of a possible initial overreaction to news events which is reversed somewhat in subsequent periods. Significant coefficients confirm the well-documented evidence day of the week effect on volatility, while non-significant coefficients for news frequency provides little support for the mixture of distributions hypothesis. Importantly, while volatility tends to increase during recessionary periods the coefficients are not well-defined. Instead, the significant coefficients for the interaction terms (Columns 3 and 6) suggest that it is the presence of news during a recession that impacts volatility and not merely the fact that the business cycle is in a recession stage; in particular a well-defined negative coefficient indicates that positive (negative) news during a recession will decrease (increase) the volatility of returns in the gold futures market.

Having identified that the volatility of gold futures reacts to relevant news sentiment, Eq. (2) is augmented to include disaggregated positive and negative news components and the results are reported in Panel B of Table 2. The intercept is again found to be negative (significantly so) indicating that volatility will decrease in the absence of newswire messages. The day of the week effect is also re-confirmed. Positive news sentiment does not have a significant effect on either volatility measure. The negative and significant coefficient for negative news sentiment indicates that negative news results in an increase in return volatility (since the variable takes a value $\leq 0$ ). As with the evidence in Panel A, the lagged news sentiment variables take the opposite sign, suggesting that there may be some initial over-reaction to newswire messages. Importantly, the interaction coefficients of news sentiment and recession provide evidence that negative news sentiment has a significant additional impact on contemporaneous volatility during recession; positive news has no significant impact on volatility, while negative (but not well-defined) lagged coefficients of negative news suggest that there is some volatility persistence following negative news releases during a recession. 


\subsection{News sentiment and conditional volatility in a TGARCH framework}

This section considers the conditional relationship between volatility of returns and news sentiment in a TGARCH framework. The results for model specifications of the form noted in Eq. (3A) and Eq. (3B) are presented in Table 3 for both consolidated and disaggregated measures of news sentiment; note that Akaike Information Criterion (AIC) is optimised at one lag of news sentiment.

$<$ Insert Table 3>

Considering the conditional returns (Panel A) first; there are significant negative first order autocorrelations and no evidence of a day of the week effect. The results for consolidated news (column 1) are as one would expect such that there is a positive and significant coefficient indicating that contemporaneous returns are positive (negative) in the presence of positive (negative) news sentiment. The negative coefficient for lagged (consolidated) news is supportive of the suggestion in the unconditional study that there is some initial overreaction to news sentiment that is reversed in subsequent periods. The coefficients for the impact of disaggregated news on conditional returns (column 2) are also as one might expect, that is positive news induces an increase in returns, while negative news reduces returns ${ }^{13}$; the magnitude of the coefficient for negative news is much larger (1.6x) than that for positive news suggesting an asymmetric impact on conditional returns. Again, the lagged news effect reverses sign providing evidence of initial overreaction to news. Importantly, recession appears to have a significant positive impact on returns under both specifications.

Panel B reports the results for the conditional variance specification (Eq.(3B)) which is the primary focus in this paper. The results for the consolidated news (column 3) and disaggregated news (column 4) find that both the ARCH term $\left(\varepsilon_{t-1}^{2}\right)$ and the GARCH term $\left(\sigma_{t-1}^{2}\right)$ are highly significant indicating persistence in volatility levels (i.e. high volatility is followed by high volatility while low volatility follows low volatility). The coefficient for the threshold variable $\left(\varepsilon_{t-1}^{2} \Gamma_{t-1}\right)$ is significant and negative indicating asymmetry in conditional volatility resulting from innovations in returns. Examining consolidated news first, the negative coefficient for contemporaneous news indicates that as news sentiment becomes more positive (negative) there is a decrease (increase) in conditional volatility. The lagged news variable has the opposite sign to

\footnotetext{
${ }^{13}$ Note that while the reported coefficient is negative the variable is always $\leq 0$, thus returns will be lower should a story with negative sentiment hit the newswires.
} 
the contemporaneous one, providing additional support for the notion that there may be some initial over-reaction to news that is reversed. Consideration of disaggregated news sentiment reveals that the impact of news is concentrated in that of negative news; the coefficients confirm the existence of an asymmetric effect on volatility such that negative news has a statistically significant coefficient more than 10 times greater than the insignificant positive news coefficient. Again, when considering lagged news measures there is some support for the possibility of initial market over-reaction to news. Finally, there is evidence that recession has a positive and significant impact on conditional variance; that is the conditional volatility of gold futures prices increases during the recession of 2007-2009.

\section{$<$ Insert Table 4>}

Table 4 sub-divides the sample into three sub-samples; pre-recession (Jan 2003 - Sep 2007), recession (Oct 2007 - June 2009), and post-recession (July 2009 - Oct 2012). Comparing the conditional return equations for each of the sub-periods reveals that news sentiment has the greatest contemporaneous impact during the recessionary period (the coefficient for newst during this period is $1.4 \mathrm{x}$ that prior to recession and $1.6 \mathrm{x}$ that post-recession), and there is further evidence of an asymmetric impact of news on returns with the coefficient for negative news sentiment proving greater in all three sub-samples.

Examination of the conditional variance equation reveals that, in the absence of news, volatility is generally higher during the recession period (statistically significant and positive constant term) and that there is persistence in the volatility measure across all sample periods. Interestingly, during the recession period there is no asymmetry of return innovations but there is evidence of an asymmetric effect of news sentiment. Positive news sentiment has the greatest magnitude of impact on volatility during the recession, perhaps as a result of positive news been relatively rare and thus surprising during this period, but the coefficients are not statistically significant. The coefficients for negative news sentiment are statistically significant across all periods, although the magnitude is greatest during the post-recession period during which market participants have been subject to newswire messages relating to the European sovereign debt crisis.

In summary, the empirical analysis presented in this section finds evidence that news sentiment has a significant asymmetric effect on the volatility of returns in the gold futures 
market, and the magnitude of this effect varies with the state of the economy. Additionally, there is some evidence of an initial over-reaction to news that is subsequently reversed.

\section{Robustness test: News as an endogenous variable}

To this point, news has been assumed to be determined exogenously to volatility as in Groß-Klußmann and Hautsch (2011), Leinweber and Sisk (2011), Riordan et al. (2013) and Smales (2014). However, the mixture of distributions hypothesis suggests that news and volatility may be determined simultaneously, and so it is important to understand whether this assumption has an impact in the identified asymmetric relationship. A reduced form Vector Autoregressive (VAR) specification of the following form is utilised:

$$
y_{t}=c+\sum_{i=1}^{p}\left(\Gamma_{i} y_{t-i}\right)+\varepsilon_{t}
$$

Where $y_{t}$ is a vector of endogenous variables including the two measures of volatility identified earlier (Vol_1 and Vol_2) and news variables (news), $p>0$ is an integer, and $\varepsilon_{t}$ is an error term. The coefficient estimates are reported in Table $5^{14}$, with estimates for a consolidated news variable in Panel A, and disaggregated news variables in Panel B. The results confirm the positive auto-correlation of both volatility and news sentiment reported in the summary statistics (Table 1). In addition, emphasising the importance of negative news is the result that lagged negative news significantly and positively influences positive news (i.e. positive news tends to follow negative news) but the reverse is not true. Most importantly, the reported results show that lagged volatility does not have a significant impact on news, but lagged news sentiment has a significant impact on current period volatility; once again this relationship is of a greater magnitude (and highly significant) for negative news sentiment rather than positive news sentiment. In summary, considering news sentiment as an endogenous variable within a VAR framework confirms the empirical results reported in Section 4, and identify an asymmetric volatility response to news sentiment.

\footnotetext{
$<$ Insert Table 5>
}

\footnotetext{
${ }^{14}$ AIC is used to determine the appropriate number of lags to use as 4 in both the consolidated and disaggregated case. For the sake of brevity, the table reports the estimated coefficients for only the first two lags.
} 


\section{Conclusion}

This paper seeks to consider the relationship between the sentiment of newswire messages and the volatility of returns in the gold futures market; a market which has had considerable growth in interest from both investors and media in the past decade.

The empirical evidence presented in this paper is broadly consistent with the extant literature on the equity and interest rate markets which reports an asymmetric impact of news which varies with the business cycle. The sentiment of newswire messages has a significant impact on the volatility of returns in the gold market. Unconditional analysis suggests that there is strong evidence of an asymmetric effect of news such that negative news has a much greater impact on volatility than does positive news.

A recessionary economic environment serves to significantly increase the impact of news sentiment on volatility, particularly the contemporaneous effect of negative news. Considering the conditional relationship between volatility and news sentiment in a TGARCH framework reveals further evidence of a significant asymmetric impact; negative newswire messages have a much greater impact on both returns and volatility than do positive messages. Additionally, there is some support for the notion that participants in the gold futures market initially over-react to newswire messages (in terms of returns and volatility) and this is reversed somewhat in subsequent periods.

Evidence that negative news creates an increase in return volatility, particularly during recession when there is a preponderance of negative news, will be of some concern to investors who may seek to invest in gold as a safe haven during times of recession - although this concern will be offset somewhat by the additional conditional returns generated during recession. Future research could consider the impact of newswire messages at a higher frequency, and also across a greater range of future markets. It may also be of some interest to understand how commodityspecific news impacts the returns, and volatility, of stocks in which the primary output of those corporations is commodity related. 


\section{References}

Antweiler, W., and M.Z. Frank, 2004, Is all that talk just noise? The information content of internet stock message boards, Journal of Finance, 59, 1259-1294

Baur, D.G., and B.M. Lucey, 2010, Is gold a hedge or a safe haven? An analysis of stocks, bonds and gold, The Financial Review, 45, 217-229

Baur, D.G., and T.K. McDermott, 2010, Is gold a safe haven? International evidence, Journal of Banking \& Finance, 34, 1886-1898

Brooks, R.M., A. Patel, and T. Su, 2003, How the equity market responds to unanticipated events, Journal of Business, 76, 109-133

Capie. F., T.C. Mills, and G. Wood, 2005, Gold as a hedge against the dollar, Journal of International Financial Markets, Institutions and Money, 15 (4), 343-352

Draper, P., D. Hillier, and R. Faff, 2006, Do precious metals shine? An investment perspective, Financial Analysts Journal, 62 (2), 98-106

Dzielinski, M., 2011, News sensitivity and the cross-section of stock returns, NCCR Finrisk working paper no. 719

Ederington, L., and J. Lee, 1993, How markets process information: News releases and volatility, Journal of Finance, 48, 1161-1191

Erb, C.B., and C.R. Harvey, 2013, The golden dilemma, Financial Analysts Journal, 69 (4), 10-42

Frino, A., and A. Hill, 2001, Intraday futures market behaviour around major scheduled macroeconomic announcements: Australian evidence, Journal of Banking \& Finance, 25, 13191337

Foster, F.D., and S. Viswanathan, 1990, A theory of interday variations in volumes, variances and trading costs in security markets, Review of Financial Studies, 3, 593-624

Foster, F.D., and S. Viswanathan, 1993, Variations in trading volume, return volatility, and trading costs: Evidence on recent price formation models, Journal of Finance, 48, 187-211

Fleming, M., and E. Remolona, 1997, What moves the bond market? FRBNY Economic Policy Review, Dec, 31-50

French, K.R., and R. Roll, 1986, Stock return variances: The arrival of information and the reaction of traders, Advances in Behavioural Finance, 219-245

Garcia, D., 2013, Sentiment during recessions, Journal of Finance, 68, 1267-1300

Gerlach, J.R., 2005, Imperfect information and stock market volatility, Financial Review, 40, 173194 
Groß-Klußmann, A., and N. Hautsch, 2011, When machines read the news: Using automated text analytics to quantify high frequency news-implied market reactions, Journal of Empirical Finance, 18, 321-340

Hamilton, J.D., and G. Lin, 1996, Stock market volatility and the business cycle, Journal of Applied Econometrics, 11, 573-593

Han, L-M, J.L. King, and C.W. Sell, 1999, Foreign exchange futures volatility: Day-of-the week, intraday, and maturity patterns in the presence of macroeconomic announcements, Journal of Futures Markets, 19, 665-693

Ho, K-Y, Y. Shi, and Z. Zhang, 2013, How does news sentiment impact asset volatility? Evidence from long memory and regime-switching approaches, North American Journal of Economics and Finance, forthcoming

Jensen, G., J. Mercer, and R. Johnson, 1996, Business conditions, monetary policy, and expected security returns, Journal of Financial Economics, 40, 213-237

Kalev, P.S., W-M. Liu, P.K. Pham, and E. Jarnecic, 2004, Public information arrival and volatility of intraday stock returns, Journal of Banking \& Finance, 28, 1441-1467

Kandel, S., and R.F. Stambaugh, 1990, Expectations and volatility of consumption and asset returns, Review of Financial Studies, 3, 207-232

Kim, O., and R.E. Verrecchia, 1994, Market liquidity and volume around earnings announcements, Journal of Accounting and Economics, 17, 41-67

Krinsky, I., and J. Lee, 1996, Earnings announcements and the components of the bid-ask spread, Journal of Finance, 51, 1523-1535

Lee, C.M.C., 1992, Earnings news and small traders: An intraday analysis, Journal of Accounting and Economics, 15, 265-302

Lee, C.M.C., B. Mucklow, and M.J. Ready, 1993, Spreads, depths and the impact of earnings information: An intraday analysis, Review of Financial Studies, 6, 345-374

Leinweber, D., and J. Sisk, 2011, Event driven trading and the 'new news', Journal of Portfolio Management, 38, 110-124

McCown, J.R., and J.R. Zimmerman, 2006, Is gold a zero-beta asset? Analysis of the investment potential of precious metals, Working Paper

McQueen, G., and V.V. Roley, 1993, Stock prices, news, and business conditions, Review of Financial Studies, 6, 683-707 
Riordan, R., A. Storkenmaier, M. Wagener, and S.S. Zhang, 2013, Public information arrival: Price discovery and liquidity in electronic order markets, Journal of Banking \& Finance, 37, 11481159

Roley, V., and G. Sellon, 1995, Monetary policy actions and long-term interest rates, Economic Quarterly, 80, 73-89

Smales, L.A., 2014, Non-scheduled news arrival and high-frequency stock market dynamics: Evidence from the Australian stock exchange, Research in International Business and Finance, 32, $122-138$

Smales, L.A., 2013, Impact of macroeconomic announcements on interest rate futures: Evidence from Australia, Journal of Financial Research, 36, 371-388

Tetlock, P.C., 2007, Giving content to investor sentiment: The role of media in the stock market, Journal of Finance, 62, 1139-1168

Tetlock, P.C., M. Saar-Tsechansky, and S. Macskassy, 2008, More than words: Quantifying language to measure firms' fundamentals, Journal of Finance, 63, 1437-1467

Veronesi, P., 1999, Stock market overreaction to bad news in good times: A rational expectations equilibrium model, Review of Financial Studies, 12, 975-1007 


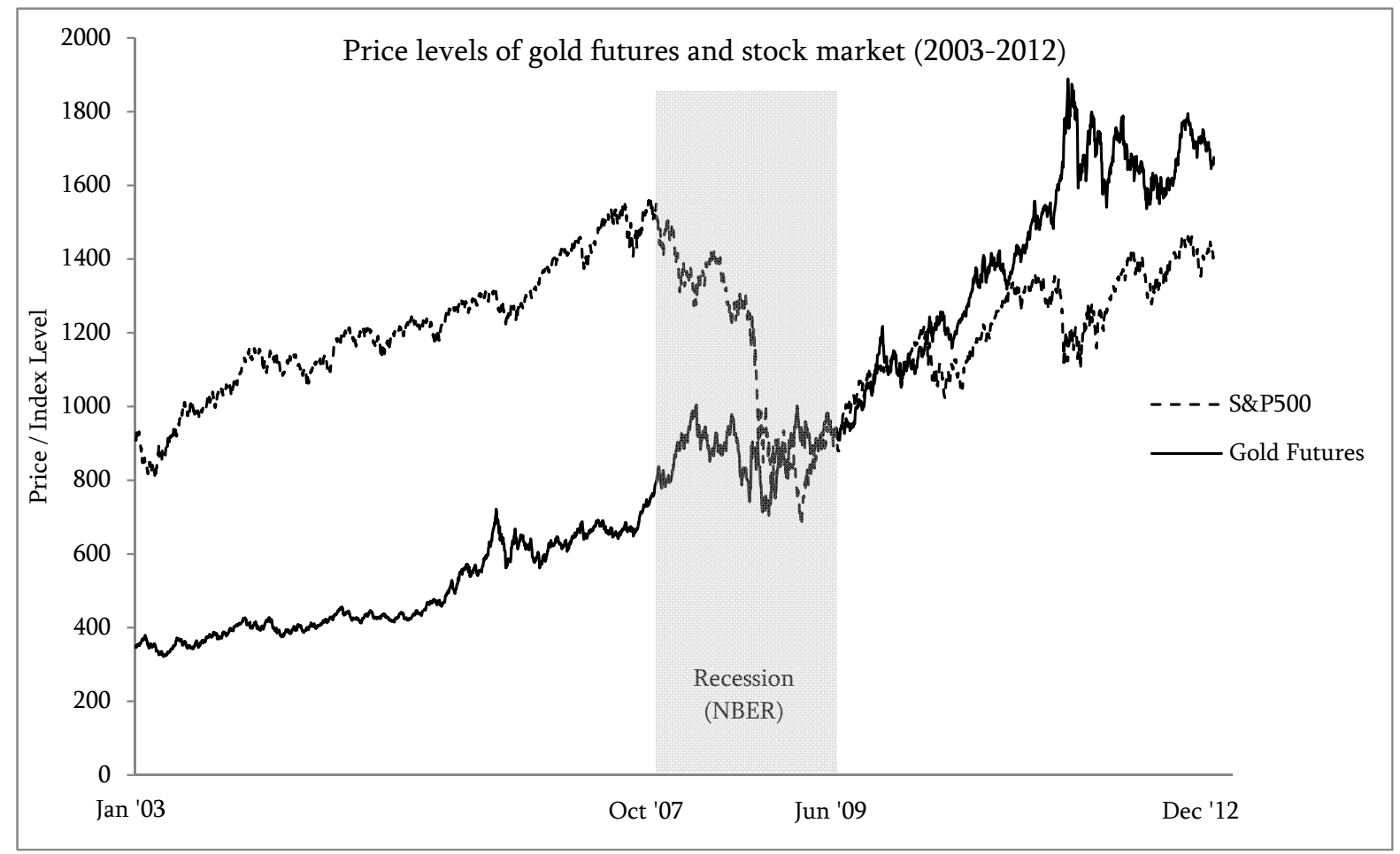

Figure 1

Evolution of the price levels of gold futures and the U.S. stock market over the period 2003 - 2012. 
Table 1

Descriptive statistics

This table presents descriptive statistics for the variables utilised in this study, using daily observations for the period 03 Jan 2003 - 13 October 2012.

Futures returns are calculated using daily closing levels, while news is a variable measuring daily news sentiment based on eq.(1). Vol_1 is a measure of volatility based on the daily standard deviation of 5-minute returns, while Vol_2 is the average daily standard deviation of changes in quote midpoints.

Unit root tests are conducted with trend and intercept; levels are used for returns and news sentiment whilst first differences are used for the measures of volatility. ${ }^{*}$ indicated rejection of the null of a unit root.

\begin{tabular}{lccccccccccc}
\hline Panel A & & & & & \multicolumn{4}{c}{ Partial Autocorrelation at Lag: } & \multicolumn{3}{c}{ Unit Root Test } \\
& Mean & SD & Skewness & Jarque-Bera & 1 & 2 & 3 & 4 & 5 & Statistic \\
\hline Futures Return (\%) $\left(R_{t}\right)$ & 0.065 & 1.257 & -0.288 & 1430 & 0.010 & -0.020 & -0.001 & 0.005 & 0.012 & -49.13 & $*$ \\
Vol_1 & 0.221 & 0.179 & 2.356 & 1161 & 0.903 & 0.266 & 0.159 & 0.048 & -0.007 & -24.16 & $*$ \\
Vol_2 & 0.078 & 0.089 & 19.245 & 2888 & 0.176 & 0.064 & 0.058 & 0.055 & 0.053 & -5.38 & $*$ \\
News & 0.008 & 0.103 & -0.204 & 20.21 & 0.335 & 0.088 & 0.087 & 0.055 & 0.045 & -9.44 & $*$ \\
\hline
\end{tabular}

\begin{tabular}{lcccccccc}
\hline Panel B & \multicolumn{10}{c}{ Overall } & \multicolumn{2}{c}{ Pre-recession } & Recession & \multicolumn{2}{c}{ Post-recession } \\
& Mean & SD & Mean & SD & Mean & SD & Mean & SD \\
\hline$R_{t}$ & 0.065 & 1.257 & 0.065 & 1.102 & 0.049 & 1.768 & 0.074 & 1.135 \\
Vol_1 & 0.221 & 0.179 & 0.085 & 0.045 & 0.292 & 0.110 & 0.344 & 0.196 \\
Vol_2 & 0.078 & 0.089 & 0.063 & 0.027 & 0.102 & 0.049 & 0.080 & 0.126 \\
News Frequency & 38.71 & 15.58 & 37.76 & 6.93 & 44.90 & 16.57 & 36.77 & 15.03 \\
News & 0.008 & 0.103 & 0.027 & 0.097 & -0.028 & 0.104 & 0.000 & 0.106 \\
\hline
\end{tabular}


Table 2

Estimation results for unconditional volatility

This table presents regression estimates for the relationship between volatility measures and news sentiment as set-out in Eq.(2). Panel A presents results for a consolidated news sentiment measure, while Panel B disaggregates the news sentiment measure into positive and negative components. The lag length for news sentiment is selected with the Akaike Information Criteria. Recessionary periods are as defined by the NBER. The results indicate that news sentiment has a significant impact on changes in volatility, this effect is asymmetric whereby the volatility response to negative news is greater than for positive news. Further, there is evidence that the impact of news sentiment is greater during the recessionary period. Standard errors are reported in parentheses.

\begin{tabular}{|c|c|c|c|c|c|c|c|c|c|c|c|c|c|c|c|c|c|c|c|c|c|}
\hline $\begin{array}{c}\text { Panel A: Consolidated } \\
\text { News }\end{array}$ & (1) & & $(2)$ & & (3) & & (4) & & (5) & & (6) & & $\begin{array}{c}\text { Panel B: Disaggregated } \\
\text { News }\end{array}$ & (1) & & (2) & & (3) & & (4) & \\
\hline Dependent Variable: & $\triangle V o l \_1$ & & $\triangle V o l \_1$ & & $\triangle V O I \_1$ & & $\triangle V o l \_2$ & & $\triangle V o l \_2$ & & $\triangle V o l \_2$ & & Dependent Variable: & $\triangle V O I \_1$ & & $\triangle V o l \_1$ & & $\Delta V o l \_2$ & & $\triangle V o l \_2$ & \\
\hline Constant & $\begin{array}{l}-0.150 \\
(0.090)\end{array}$ & ${ }^{*}$ & $\begin{array}{l}-0.156 \\
(0.086)\end{array}$ & ${ }^{*}$ & $\begin{array}{l}-0.179 \\
(0.094)\end{array}$ & ${ }^{*}$ & $\begin{array}{l}-0.008 \\
(0.004)\end{array}$ & ${ }^{*}$ & $\begin{array}{l}-0.034 \\
(0.017)\end{array}$ & ${ }^{* *}$ & $\begin{array}{l}-0.034 \\
(0.017)\end{array}$ & ${ }^{* *}$ & Constant & $\begin{array}{l}-0.048 \\
(0.015)\end{array}$ & ${ }^{* * *}$ & $\begin{array}{l}-0.047 \\
(0.015)\end{array}$ & ${ }^{* * *}$ & $\begin{array}{l}-0.037 \\
(0.017)\end{array}$ & ${ }^{* *}$ & $\begin{array}{l}-0.037 \\
(0.017)\end{array}$ & ${ }^{* *}$ \\
\hline News $_{t}$ & $\begin{array}{l}-1.183 \\
(0.379)\end{array}$ & $* * *$ & $\begin{array}{l}-1.184 \\
(0.380)\end{array}$ & $* * *$ & $\begin{array}{l}-0.725 \\
(0.329)\end{array}$ & ** & $\begin{array}{l}-0.037 \\
(0.018)\end{array}$ & ** & $\begin{array}{l}-0.039 \\
(0.018)\end{array}$ & ** & $\begin{array}{l}-0.032 \\
(0.015)\end{array}$ & ** & + News $_{t}$ & $\begin{array}{c}0.011 \\
(0.030)\end{array}$ & & $\begin{array}{c}0.021 \\
(0.032)\end{array}$ & & $\begin{array}{c}0.014 \\
(0.035)\end{array}$ & & $\begin{array}{c}0.008 \\
(0.038)\end{array}$ & \\
\hline News $_{t-1}$ & $\begin{array}{c}0.373 \\
(0.380)\end{array}$ & & $\begin{array}{c}0.373 \\
(0.380)\end{array}$ & & $\begin{array}{c}0.292 \\
(0.430)\end{array}$ & & $\begin{array}{c}0.008 \\
(0.018)\end{array}$ & & $\begin{array}{c}0.006 \\
(0.018)\end{array}$ & & $\begin{array}{c}0.003 \\
(0.021)\end{array}$ & & - News $_{t}$ & $\begin{array}{l}-0.154 \\
(0.029)\end{array}$ & $* * *$ & $\begin{array}{l}-0.170 \\
(0.035)\end{array}$ & $* * *$ & $\begin{array}{l}-0.091 \\
(0.034)\end{array}$ & $* * *$ & $\begin{array}{l}-0.075 \\
(0.030)\end{array}$ & ** \\
\hline $\log \left(\right.$ News_Freq $\left._{t}\right)$ & & & $\begin{array}{c}0.003 \\
(0.091)\end{array}$ & & $\begin{array}{c}0.005 \\
(0.091)\end{array}$ & & & & $\begin{array}{c}0.007 \\
(0.004)\end{array}$ & & $\begin{array}{c}0.007 \\
(0.004)\end{array}$ & * & + News $_{t-1}$ & $\begin{array}{c}0.022 \\
(0.030)\end{array}$ & & $\begin{array}{c}0.025 \\
(0.032)\end{array}$ & & $\begin{array}{c}0.000 \\
(0.034)\end{array}$ & & $\begin{array}{c}0.008 \\
(0.037)\end{array}$ & \\
\hline Recession $_{t}$ & $\begin{array}{c}0.159 \\
(0.095)\end{array}$ & * & $\begin{array}{c}0.158 \\
(0.096)\end{array}$ & & $\begin{array}{c}0.096 \\
(0.099)\end{array}$ & & $\begin{array}{c}0.010 \\
(0.045)\end{array}$ & & $\begin{array}{c}0.005 \\
(0.048)\end{array}$ & & $\begin{array}{c}0.007 \\
(0.048)\end{array}$ & & - News $_{t-1}$ & $\begin{array}{c}0.104 \\
(0.029)\end{array}$ & ${ }^{* * *}$ & $\begin{array}{c}0.139 \\
(0.035)\end{array}$ & $* * *$ & $\begin{array}{c}0.011 \\
(0.003)\end{array}$ & $* * *$ & $\begin{array}{c}0.058 \\
(0.004)\end{array}$ & $* * *$ \\
\hline News $_{\bullet}$ Recession $_{t}$ & & & & & $\begin{array}{l}-2.304 \\
(0.013)\end{array}$ & ** & & & & & $\begin{array}{l}-0.032 \\
(0.005)\end{array}$ & $* * *$ & $\log \left(\right.$ News_Freq $\left.{ }_{t}\right)$ & $\begin{array}{c}0.004 \\
(0.004)\end{array}$ & & $\begin{array}{c}0.004 \\
(0.004)\end{array}$ & & $\begin{array}{c}0.007 \\
(0.004)\end{array}$ & & $\begin{array}{c}0.007 \\
(0.004)\end{array}$ & \\
\hline News Recession $_{t-1}$ & & & & & $\begin{array}{l}-0.715 \\
(0.923)\end{array}$ & & & & & & $\begin{array}{c}0.007 \\
(0.004)\end{array}$ & & Recession $_{t}$ & $\begin{array}{c}0.014 \\
(0.040)\end{array}$ & & $\begin{array}{c}0.007 \\
(0.083)\end{array}$ & & $\begin{array}{c}0.006 \\
(0.047)\end{array}$ & & $\begin{array}{c}0.003 \\
(0.097)\end{array}$ & \\
\hline \multirow[t]{5}{*}{ Day $_{t}$} & $\begin{array}{c}0.039 \\
(0.023)\end{array}$ & * & $\begin{array}{c}0.039 \\
(0.023)\end{array}$ & $*$ & $\begin{array}{c}0.042 \\
(0.024)\end{array}$ & * & $\begin{array}{c}0.002 \\
(0.001)\end{array}$ & $*$ & $\begin{array}{c}0.002 \\
(0.001)\end{array}$ & $*$ & $\begin{array}{c}0.002 \\
(0.001)\end{array}$ & * & + News $^{\bullet}$ Recession $_{t}$ & & & $\begin{array}{l}-0.091 \\
(0.089)\end{array}$ & & & & $\begin{array}{c}0.040 \\
(0.103)\end{array}$ & \\
\hline & & & & & & & & & & & & & - News $\bullet$ Recession $_{t}$ & & & $\begin{array}{l}-0.052 \\
(0.007)\end{array}$ & $* * *$ & & & $\begin{array}{l}-0.056 \\
(0.008)\end{array}$ & $* * *$ \\
\hline & & & & & & & & & & & & & + News $\bullet$ Recession $_{t-1}$ & & & $\begin{array}{l}-0.058 \\
(0.089)\end{array}$ & & & & $\begin{array}{l}-0.056 \\
(0.103)\end{array}$ & \\
\hline & & & & & & & & & & & & & - News $\bullet$ Recession $_{t-1}$ & & & $\begin{array}{l}-0.104 \\
(0.067)\end{array}$ & & & & $\begin{array}{l}-0.064 \\
(0.077)\end{array}$ & \\
\hline & & & & & & & & & & & & & $\operatorname{Day}_{t}$ & $\begin{array}{c}0.010 \\
(0.001)\end{array}$ & $* * *$ & $\begin{array}{c}0.010 \\
(0.001)\end{array}$ & $* * *$ & $\begin{array}{c}0.002 \\
(0.001)\end{array}$ & ** & $\begin{array}{c}0.002 \\
(0.001)\end{array}$ & ** \\
\hline Adj. $R^{2}$ & 0.089 & & 0.101 & & 0.117 & & 0.029 & & 0.024 & & 0.025 & & $\operatorname{Adj} . R^{2}$ & 0.104 & & 0.109 & & 0.030 & & 0.031 & \\
\hline F-statistic & 5.46 & & 4.37 & & 4.28 & & 6.21 & & 6.18 & & 6.14 & & $F$-statistic & 17.02 & & 11.44 & & 10.76 & & 10.22 & \\
\hline Durbin-Watson & 2.08 & & 2.08 & & 2.08 & & 2.14 & & 2.14 & & 2.14 & & Durbin-Watson & 2.58 & & 2.58 & & 2.14 & & 2.14 & \\
\hline
\end{tabular}

$* *,{ }^{* *},{ }^{*}$ indicate statistical significance at the $0.01,0.05$, and 0.10 level respectively 
Table 3

\section{Estimation results for conditional returns and volatility}

This table presents regression estimates for the relationship between conditional returns and volatility of gold futures in a Threshold GARCH model as set out in Eq.(3A) and Eq.(3B). Panel A presents results for a conditional returns, while Panel B presents results for the conditional variance equation. The lag length for news sentiment is selected with the Akaike Information Criteria. Recessionary periods are as defined by the NBER. The results indicate that news sentiment has a significant impact on changes in volatility, this effect is asymmetric whereby the volatility response to negative news is greater than for positive news. There is also evidence of an asymmetric response to return innovations. Further, there is evidence that the response of both returns and volatility of returns in the gold futures market owing to news sentiment is higher during the recessionary period. Standard errors are reported in parentheses.

\begin{tabular}{|c|c|c|c|c|c|c|c|c|c|}
\hline $\begin{array}{c}\text { Panel A } \\
\text { Conditional Return } \\
\text { Equation }\end{array}$ & $\begin{array}{c}\text { Consolidat } \\
\text { News }\end{array}$ & & $\begin{array}{r}\text { Disaggrega } \\
\text { News }\end{array}$ & & $\begin{array}{c}\text { Panel B } \\
\text { Conditional } \\
\text { Variance Equation }\end{array}$ & $\begin{array}{r}\text { Consolida } \\
\text { News }\end{array}$ & & $\begin{array}{c}\text { Disaggrega } \\
\text { News }\end{array}$ & \\
\hline Constant & $\begin{array}{c}0.008 \\
(0.052)\end{array}$ & & $\begin{array}{c}0.106 \\
(0.060)\end{array}$ & $*$ & Constant & $\begin{array}{l}-0.023 \\
(0.029)\end{array}$ & & $\begin{array}{l}-0.053 \\
(0.031)\end{array}$ & $*$ \\
\hline$y_{t-1}$ & $\begin{array}{l}-0.065 \\
(0.021)\end{array}$ & $* * *$ & $\begin{array}{l}-0.069 \\
(0.021)\end{array}$ & *** & $\varepsilon_{t-1}^{2}$ & $\begin{array}{c}0.060 \\
(0.007)\end{array}$ & $* * *$ & $\begin{array}{c}0.065 \\
(0.008)\end{array}$ & $* * *$ \\
\hline $\mathrm{NeWs}_{t}$ & $\begin{array}{c}4.772 \\
(0.203)\end{array}$ & $* * *$ & & & $\sigma_{t-1}^{2}$ & $\begin{array}{c}0.942 \\
(0.007)\end{array}$ & $* * *$ & $\begin{array}{c}0.936 \\
(0.008)\end{array}$ & *** \\
\hline NeWs $_{t-1}$ & $\begin{array}{l}-1.566 \\
(0.215)\end{array}$ & $* * *$ & & & $\varepsilon_{t-1}^{2} \Gamma_{t-1}$ & $\begin{array}{l}-0.030 \\
(0.008)\end{array}$ & $* * *$ & $\begin{array}{l}-0.037 \\
(0.008)\end{array}$ & $* * *$ \\
\hline$+{ }^{N e w s}{ }_{t}$ & & & $\begin{array}{c}3.868 \\
(0.369)\end{array}$ & $* * *$ & $\mathrm{NeWs}_{t}$ & $\begin{array}{l}-1.116 \\
(0.190)\end{array}$ & $* * *$ & & \\
\hline$-\mathrm{News}_{t}$ & & & $\begin{array}{c}6.198 \\
(0.469)\end{array}$ & $* * *$ & News $s_{t-1}$ & $\begin{array}{c}1.182 \\
(0.188)\end{array}$ & $* * *$ & & \\
\hline+ NeWs $_{t-1}$ & & & $\begin{array}{l}-1.645 \\
(0.373)\end{array}$ & $* * *$ & + News ${ }_{t}$ & & & $\begin{array}{c}0.335 \\
(0.365)\end{array}$ & \\
\hline$-N e w s_{t-1}$ & & & $\begin{array}{l}-1.344 \\
(0.400)\end{array}$ & $* * *$ & $-\mathrm{News}_{t}$ & & & $\begin{array}{l}-3.940 \\
(0.519)\end{array}$ & $* * *$ \\
\hline Recession $_{t}$ & $\begin{array}{c}0.161 \\
(0.073)\end{array}$ & ** & $\begin{array}{c}0.192 \\
(0.072)\end{array}$ & ** & + News ${ }_{t-1}$ & & & $\begin{array}{c}0.058 \\
(0.364)\end{array}$ & \\
\hline \multirow[t]{4}{*}{$\operatorname{Day}_{t}$} & $\begin{array}{c}0.003 \\
(0.015)\end{array}$ & & $\begin{array}{c}0.004 \\
(0.014)\end{array}$ & & - NeWs $_{t-1}$ & & & $\begin{array}{c}3.610 \\
(0.468)\end{array}$ & $* * *$ \\
\hline & & & & & Recession $_{t}$ & $\begin{array}{c}0.025 \\
(0.007)\end{array}$ & $* * *$ & $\begin{array}{c}0.024 \\
(0.008)\end{array}$ & $* * *$ \\
\hline & & & & & $\operatorname{Day}_{t}$ & $\begin{array}{c}0.012 \\
(0.010)\end{array}$ & & $\begin{array}{c}0.014 \\
(0.010)\end{array}$ & \\
\hline & & & & & $\begin{array}{l}\text { Adj. } R^{2} \\
\text { Log-Likelihood } \\
\text { Durbin Watson }\end{array}$ & $\begin{array}{c}0.162 \\
-3603.95 \\
2.04\end{array}$ & & $\begin{array}{c}0.168 \\
-3580.60 \\
2.010\end{array}$ & \\
\hline
\end{tabular}

${ }^{* * *},{ }^{* *},{ }^{*}$ indicate statistical significance at the $0.01,0.05$, and 0.10 level respectively 
Table 4

Estimation results for sub-sample analysis of conditional returns and volatility

This table presents regression estimates for the relationship between conditional returns and volatility of gold futures in a Threshold GARCH model as set out in Eq.(3A) and Eq.(3B) with the sample period segmented in relationship to NBER defined recessionary periods. Panel A presents results for a conditional returns, while Panel B presents results for the conditional variance equation. The lag length for news sentiment is selected with the Akaike Information Criteria. Recessionary periods are as defined by the NBER. The results indicate that news sentiment has a significant impact on changes in volatility, this effect is asymmetric whereby the volatility response to negative news is greater than for positive news. Further, there is evidence that the response of both returns and volatility of returns in the gold futures market owing to news sentiment is higher during the recessionary period. Standard errors are reported in parentheses.

\begin{tabular}{|c|c|c|c|c|c|c|c|c|c|c|c|c|}
\hline \multirow{3}{*}{$\begin{array}{c}\text { Conditional Return } \\
\text { Equation }\end{array}$} & \multicolumn{4}{|c|}{ Pre-Recession (Jan '03 - Sep '07) } & \multicolumn{4}{|c|}{ Recession (Oct '07 - Jun '09) } & \multicolumn{4}{|c|}{ Post-Recession (Jul '09 - Oct '12) } \\
\hline & \multirow{2}{*}{\multicolumn{2}{|c|}{$\begin{array}{c}\text { Consolidated } \\
\text { News }\end{array}$}} & \multicolumn{2}{|c|}{ Disaggregated } & \multicolumn{2}{|c|}{ Consolidated } & \multicolumn{2}{|c|}{ Disaggregated } & \multicolumn{2}{|c|}{ Consolidated } & \multicolumn{2}{|c|}{ Disaggregated } \\
\hline & & & \multicolumn{2}{|c|}{ News } & \multicolumn{2}{|c|}{ News } & \multicolumn{2}{|c|}{ News } & \multicolumn{2}{|c|}{ News } & \multicolumn{2}{|c|}{ News } \\
\hline \multirow[t]{2}{*}{ Constant } & -0.002 & & 0.136 & ${ }^{*}$ & 0.178 & & 0.468 & & -0.001 & & 0.017 & \\
\hline & $(0.069)$ & & $(0.080)$ & & $(0.182)$ & & $(0.336)$ & & $(0.091)$ & & $(0.104)$ & \\
\hline \multirow[t]{2}{*}{$y_{t-1}$} & -0.112 & $* * *$ & -0.115 & *** & -0.024 & & 0.013 & & -0.050 & & -0.061 & \\
\hline & $(0.030)$ & & $(0.029)$ & & $(0.052)$ & & $(0.069)$ & & $(0.038)$ & & $(0.038)$ & \\
\hline \multirow[t]{2}{*}{ News $_{t}$} & 4.878 & *** & & & 6.818 & *** & & & 4.218 & $* * *$ & & \\
\hline & $(0.290)$ & & & & $(0.515)$ & & & & $(0.327)$ & & & \\
\hline \multirow[t]{2}{*}{ News $s_{t-1}$} & -0.947 & $* * *$ & & & -1.864 & ** & & & -2.039 & $* * *$ & & \\
\hline & $(0.299)$ & & & & $(0.767)$ & & & & $(0.340)$ & & & \\
\hline+ News $_{t}$ & & & 4.008 & $* * *$ & & & 4.660 & ** & & & 3.477 & $* * *$ \\
\hline & & & $(0.460)$ & & & & $(2.237)$ & & & & $(0.728)$ & \\
\hline$-N e w s_{t}$ & & & 6.355 & *** & & & 8.717 & *** & & & 5.431 & ${ }^{* * *}$ \\
\hline & & & $(0.714)$ & & & & $(1.484)$ & & & & $(0.808)$ & \\
\hline+ NeWs $_{t-1}$ & & & -1.582 & $* * *$ & & & -1.169 & & & & -1.322 & ** \\
\hline & & & $(0.474)$ & & & & (1.813) & & & & $(0.606)$ & \\
\hline$-N e w s_{t-1}$ & & & 0.076 & & & & -2.987 & *** & & & -2.835 & ${ }^{* * *}$ \\
\hline & & & $(0.637)$ & & & & (1.175) & & & & $(0.618)$ & \\
\hline Day $_{t}$ & -0.011 & & -0.009 & & -0.013 & & -0.007 & & 0.030 & & 0.032 & \\
\hline & $(0.019)$ & & $(0.019)$ & & $(0.055)$ & & $(0.076)$ & & $(0.026)$ & & $(0.025)$ & \\
\hline Conditional Variance & & & & & & & & & & & & \\
\hline Equation & & & & & & & & & & & & \\
\hline Constant & -0.001 & & -0.023 & & 0.693 & $* * *$ & 2.248 & ** & -0.025 & & 0.015 & \\
\hline & $(0.036)$ & & $(0.036)$ & & $(0.261)$ & & $(0.949)$ & & $(0.082)$ & & $(0.092)$ & \\
\hline$\varepsilon_{t-1}^{2}$ & 0.039 & $* * *$ & 0.042 & $* * *$ & 0.042 & ** & 0.108 & $*$ & 0.078 & $* * *$ & 0.085 & $* * *$ \\
\hline & $(0.010)$ & & $(0.012)$ & & $(0.020)$ & & $(0.057)$ & & $(0.013)$ & & $(0.017)$ & \\
\hline$\sigma_{t-1}^{2}$ & 0.971 & $* * *$ & 0.969 & $* * *$ & 0.953 & $* * *$ & 0.944 & $* * *$ & 0.940 & $* * *$ & 0.923 & *** \\
\hline & $(0.007)$ & & $(0.007)$ & & $(0.023)$ & & (0.198) & & $(0.016)$ & & $(0.019)$ & \\
\hline$\varepsilon_{t-1}^{2} \Gamma_{t-1}$ & -0.026 & ** & -0.030 & ** & -0.020 & & -0.011 & & -0.053 & *** & -0.054 & ${ }^{* * *}$ \\
\hline & $(0.011)$ & & $(0.012)$ & & $(0.030)$ & & $(0.081)$ & & $(0.013)$ & & $(0.016)$ & \\
\hline $\mathrm{News}_{t}$ & -0.638 & $* * *$ & & & -3.595 & $* * *$ & & & -1.510 & $* * *$ & & \\
\hline & $(0.246)$ & & & & $(0.967)$ & & & & $(0.365)$ & & & \\
\hline News $_{t-1}$ & 0.747 & $* * *$ & & & 2.743 & *** & & & 1.574 & $* * *$ & & \\
\hline & $(0.240)$ & & & & $(1.057)$ & & & & $(0.364)$ & & & \\
\hline+ News $_{t}$ & & & 0.057 & & & & -6.009 & & & & 1.725 & $*$ \\
\hline & & & $(0.393)$ & & & & (4.298) & & & & $(0.090)$ & \\
\hline$-N e w s_{t}$ & & & -2.515 & $* * *$ & & & -2.797 & $* * *$ & & & -6.380 & $* * *$ \\
\hline & & & $(0.718)$ & & & & (1.267) & & & & $(1.181)$ & \\
\hline+ News $_{t-1}$ & & & 0.201 & & & & -7.171 & & & & -1.321 & \\
\hline & & & $(0.407)$ & & & & $(5.926)$ & & & & $(0.889)$ & \\
\hline$-N e w s_{t-1}$ & & & 2.398 & $* * *$ & & & 2.463 & ** & & & 5.951 & *** \\
\hline & & & $(0.721)$ & & & & $(1.162)$ & & & & (1.136) & \\
\hline $\operatorname{Day}_{t}$ & 0.000 & & 0.004 & & 0.241 & ** & 0.203 & $* *$ & 0.012 & & -0.008 & \\
\hline & $(0.018)$ & & $(0.011)$ & & $(0.085)$ & & $(0.096)$ & & $(0.027)$ & & $(0.029)$ & \\
\hline $\operatorname{Adj} . R^{2}$ & 0.207 & & 0.213 & & 0.166 & & 0.176 & & 0.143 & & 0.147 & \\
\hline Log-Likelihood & -1595.96 & & -1586.90 & & -791.98 & & -823.14 & & -1178.16 & & -1164.85 & \\
\hline Durbin Watson & 2.00 & & 2.01 & & 2.01 & & 1.99 & & 1.98 & & 1.98 & \\
\hline
\end{tabular}

${ }^{* * *},{ }^{* *},{ }^{*}$ indicate statistical significance at the $0.01,0.05$, and 0.10 level respectively 
Table 5

Estimation results for VAR specification

This table presents coefficient estimates for the relationship between volatility measures and news sentiment as set-out in the VAR specification of Eq.(4). Panel A presents results for a consolidated news sentiment measure, while Panel B disaggregates the news sentiment measure into positive and negative components. The appropriate lag length for news sentiment is selected with the Akaike Information Criteria, and the first two legs are reported here. The results indicate that lagged news sentiment has a significant impact on changes in volatility, this effect is asymmetric whereby the volatility response to negative news is greater than for positive news. Conversely, lagged volatility does not appear to have a significant impact on news sentiment. Standard errors are reported in parentheses.

\begin{tabular}{|c|c|c|c|c|c|c|c|c|c|c|c|c|c|c|c|c|c|c|c|c|}
\hline \multirow{3}{*}{$\begin{array}{c}\text { News } \\
\text { Dependent Variable: }\end{array}$} & \multicolumn{7}{|c|}{ Panel A: Consolidated News } & & \multicolumn{12}{|c|}{ Panel B: Disaggregated News } \\
\hline & \multicolumn{4}{|c|}{ (1) } & \multicolumn{3}{|c|}{ (2) } & & \multicolumn{6}{|c|}{ (3) } & \multicolumn{6}{|c|}{ (4) } \\
\hline & $\triangle V o l \_1$ & & $\mathrm{NeWs}_{t}$ & & $\triangle$ Vol_2 & & News $_{t}$ & & $\triangle$ Vol_1 & & $+\mathrm{NeWs}_{t}$ & & - News $_{t}$ & & $\triangle$ Vol_2 & & $+{ }^{N e W s_{t}}$ & & - News $_{t}$ & \\
\hline Constant & $\begin{array}{c}0.012 \\
(0.002)\end{array}$ & $* * *$ & $\begin{array}{c}0.917 \\
(0.267)\end{array}$ & *** & $\begin{array}{c}0.157 \\
(0.003)\end{array}$ & $* * *$ & $\begin{array}{l}-0.075 \\
(0.368)\end{array}$ & & $\begin{array}{l}0.013 \\
(0.004)\end{array}$ & *** & $\begin{array}{c}2.636 \\
(0.214)\end{array}$ & *** & $\begin{array}{l}-1.719 \\
(0.263)\end{array}$ & *** & $\begin{array}{l}0.014 \\
(0.004)\end{array}$ & **** & $\begin{array}{c}1.928 \\
(0.240)\end{array}$ & *** & $\begin{array}{l}-2.068 \\
(0.296)\end{array}$ & *** \\
\hline$V o l \_i_{t-1}$ & $\begin{array}{c}0.614 \\
(28.922)\end{array}$ & *** & $\begin{array}{l}-3.863 \\
(2.286)\end{array}$ & * & $\begin{array}{c}0.671 \\
(0.039)\end{array}$ & *** & $\begin{array}{l}-6.338 \\
(4.321)\end{array}$ & & $\begin{array}{c}0.613 \\
(0.021)\end{array}$ & *** & $\begin{array}{l}-0.228 \\
(1.230)\end{array}$ & & $\begin{array}{l}-3.463 \\
(1.913)\end{array}$ & * & $\begin{array}{c}0.671 \\
(0.039)\end{array}$ & *** & $\begin{array}{l}-2.022 \\
(2.322)\end{array}$ & & $\begin{array}{l}-4.165 \\
(2.863)\end{array}$ & \\
\hline$V o l \_i_{t-2}$ & $\begin{array}{c}0.155 \\
(6.253)\end{array}$ & *** & $\begin{array}{c}3.913 \\
(2.672)\end{array}$ & & $\begin{array}{c}0.079 \\
(0.042)\end{array}$ & * & $\begin{array}{l}-6.025 \\
(4.609)\end{array}$ & & $\begin{array}{c}0.155 \\
(0.025)\end{array}$ & *** & $\begin{array}{l}-0.832 \\
(1.435)\end{array}$ & & $\begin{array}{c}3.769 \\
(1.765)\end{array}$ & & $\begin{array}{c}0.078 \\
(0.042)\end{array}$ & * & $\begin{array}{l}-3.030 \\
(2.476)\end{array}$ & & $\begin{array}{l}-3.086 \\
(3.052)\end{array}$ & \\
\hline News $_{t-1}$ & $\begin{array}{l}-0.530 \\
(0.200)\end{array}$ & $* * *$ & $\begin{array}{c}0.249 \\
(0.021)\end{array}$ & $* * *$ & $\begin{array}{l}-0.840 \\
(0.200)\end{array}$ & $* * *$ & $\begin{array}{c}0.267 \\
(0.021)\end{array}$ & $* * *$ & & & & & & & & & & & & \\
\hline $\mathrm{NeWs}_{t-2}$ & $\begin{array}{l}-0.406 \\
(0.200)\end{array}$ & $* *$ & $\begin{array}{c}0.075 \\
(0.022)\end{array}$ & $* * *$ & $\begin{array}{l}-0.349 \\
(0.200)\end{array}$ & * & $\begin{array}{c}0.069 \\
(0.022)\end{array}$ & $* * *$ & & & & & & & & & & & & \\
\hline$+{ }_{N e w s} s_{t-1}$ & & & & & & & & & $\begin{array}{c}0.721 \\
(0.386)\end{array}$ & * & $\begin{array}{c}0.182 \\
(0.023)\end{array}$ & $* * *$ & $\begin{array}{c}0.033 \\
(0.029)\end{array}$ & & $\begin{array}{c}0.675 \\
(0.392)\end{array}$ & $*$ & $\begin{array}{c}0.194 \\
(0.023)\end{array}$ & $* * *$ & $\begin{array}{c}0.050 \\
(0.028)\end{array}$ & * \\
\hline$+N e w s_{t-2}$ & & & & & & & & & $\begin{array}{l}-0.260 \\
(0.326)\end{array}$ & & $\begin{array}{c}0.053 \\
(0.024)\end{array}$ & $* *$ & $\begin{array}{l}-0.011 \\
(0.029)\end{array}$ & & $\begin{array}{l}-0.191 \\
(0.412)\end{array}$ & & $\begin{array}{c}0.064 \\
(0.024)\end{array}$ & $* * *$ & $\begin{array}{l}-0.001 \\
(0.029)\end{array}$ & \\
\hline$-N e w s_{t-1}$ & & & & & & & & & $\begin{array}{l}-0.921 \\
(0.348)\end{array}$ & $* * *$ & $\begin{array}{c}0.058 \\
(0.019)\end{array}$ & *** & $\begin{array}{c}0.217 \\
(0.023)\end{array}$ & *** & $\begin{array}{l}-0.717 \\
(0.331)\end{array}$ & ** & $\begin{array}{c}0.065 \\
(0.019)\end{array}$ & *** & $\begin{array}{c}0.221 \\
(0.024)\end{array}$ & $* * *$ \\
\hline$-\mathrm{News}_{t-2}$ & & & & & & & & & $\begin{array}{l}-0.600 \\
(0.398)\end{array}$ & & $\begin{array}{l}-0.015 \\
(0.019)\end{array}$ & & $\begin{array}{c}0.080 \\
(0.023)\end{array}$ & $* *$ & $\begin{array}{l}-0.402 \\
(0.322)\end{array}$ & & $\begin{array}{l}-0.008 \\
(0.019)\end{array}$ & & $\begin{array}{c}0.082 \\
(0.024)\end{array}$ & $* * *$ \\
\hline Adj. $R^{2}$ & 0.851 & & 0.138 & & 0.187 & & 0.120 & & 0.851 & & 0.100 & & 0.122 & & 0.188 & & 0.089 & & 0.108 & \\
\hline F-statistic & 2070.8 & & 57.8 & & 83.5 & & 49.3 & & 1380.6 & & 5.6 & & 6.0 & & 55.7 & & 23.5 & & 29.0 & \\
\hline $\begin{array}{l}\text { AIC } \\
\text { Log-Likelihood }\end{array}$ & & $\begin{array}{r}4.3^{3} \\
-472\end{array}$ & & & & $\begin{array}{r}4.3 \\
-474\end{array}$ & & & & & $\begin{array}{r}8 . \\
-97\end{array}$ & $\begin{array}{l}99 \\
40.4\end{array}$ & & & & & $\begin{array}{c}9.01 \\
-9760.8\end{array}$ & & & \\
\hline
\end{tabular}

*** ** ${ }^{*}$ indicate statistical significance at the $0.01,0.05$, and 0.10 level respectively 